\title{
Sirtuin gene polymorphisms are associated with chronic obstructive pulmonary disease in patients in Muğla province
}

\author{
Serdar Kalemci ${ }^{1}$, Tuba Gokdogan Edgunlu ${ }^{2}$, Murat Kara ${ }^{3}$, Ummuhani Ozel Turkcu², Esin Sakalli Cetin ${ }^{4}$, \\ Arife Zeybek ${ }^{1}$
}

${ }^{1}$ Department of Chest Diseases, Sitki Kocman University Faculty of Medicine, Muğla, Turkey

${ }^{2}$ Department of Mugla School of Health, Sitki Kocman University, Muğla, Turkey

${ }^{3}$ Department of Genetics, Sitki Kocman University Faculty of Medicine, Muğla, Turkey

${ }^{4}$ Department of Medical Biology, Sitki Kocman University Faculty of Medicine, Muğla, Turkey

Kardiochirurgia i Torakochirurgia Polska 2014; 11 (3): 306-310

\begin{abstract}
Introduction: Chronic obstructive pulmonary disease (COPD) is an irreversible progressive chronic inflammatory disease that causes shortness of breath in consequence of a decrease in pulmonary functions. The pulmonary inflammatory pathogenesis is multifactorial. We have too little up-to-date information about the relation between COPD and genetics. In our study, the relation with the SIRT1 gene's mononucleotide polymorphisms (SNP) rs7895833, rs7069102 and rs2273773 was analyzed through various laboratory data.

Material and methods: One hundred COPD patients from the archive records of the Chest Diseases Department of Muğla Sitki Kocman University Medical Faculty were included in the study. A control group was constituted from 100 healthy individuals who live in the same geographical region. The SIRT1 genotypes for these patients were determined using polymerase chain reaction (PCR) and confronting two-pair primers (CTPP) methods. The SIRT1 gene polymorphisms rs7895833, rs7069102 and rs2273773 were analyzed. GG, AG, AA genotypes and $G$ and A alleles of rs7895833, TT, TC, CC genotypes and T and C alleles of rs 2273773 , and CC, CG, GG genotypes and C and G alleles of rs 7069102 were examined. The data in both groups were compared.

Conclusions: A significant difference between GG, AG and AA genotypes of rs7895833 was found. Especially, the AG genotype was observed more in the group with COPD, with a significant difference. A significant difference between TT, TC and CC genotypes of rs2273773 was found. There was a significant difference between two groups with regards to $C$ and $G$ alleles of rs7069102. A significant difference was not found between the groups with regards to $G$ and $A$ alleles of rs7895833. A difference was not found for both groups between $T$ and $C$ alleles of rs2273773. It shows that these polymorphisms of the SIRT1 gene may be associated with COPD.

Key words: COPD, SIRT1 gene.
\end{abstract}

\section{Streszczenie}

Wstęp: Przewlekła obturacyjna choroba płuc (POChP) jest nieodwracalną postępującą przewlekłą chorobą zapalną. Powoduje duszność wynikającą ze zmniejszonej czynności płuc. Patogeneza płucnej reakcji zapalnej jest wieloczynnikowa. Nie ma pełnych informacji na temat genetycznych uwarunkowań POChP. W opisywanym badaniu związek pomiędzy jednonukleotydowymi polimorfizmami genu SIRT1: rs7895833, rs7069102 oraz rs2273773, został zbadany poprzez analizę różnych danych laboratoryjnych.

Materiat i metody: Do badania włączono dane 100 pacjentów z POChP z archiwum Oddziału Chorób Klatki Piersiowej Wydziału Medycyny Uniwersytetu Muğla Sitki Kocman. Grupę kontrolną stanowiło 100 zdrowych osób mieszkających w tym samym regionie geograficznym. Genotypy SIRT1 pacjentów ustalono przy użyciu reakcji łańcuchowej polimerazy (PCR) i (CTPP) PCR i CTPP. Analizowano polimorfizmy rs7895833, rs7069102 oraz rs2273773 genu SIRT1. Zbadano genotypy GG, AG i AA oraz allele G i A wariantu rs7895833, genotypy TT, TC i CC oraz allele T i C wariantu rs2273773, jak również genotypy CC, CG i GG oraz allele CG wariantu rs7069102. Dane z obu grup zostały porównane.

Wnioski: Znaleziono istotną różnicę pomiędzy genotypami GG, AG i AA wariantu rs7895833. W szczególności genotyp AG obserwowany był zdecydowanie częściej w grupie z POChP. Wykazano istotną różnicę między genotypami TT, TC i CC wariantu rs2273773. Pomiędzy grupami wystąpiła również istotna różnica w odniesieniu do alleli C i G wariantu rs7069102. Nie wykazano istotnej różnicy pomiędzy grupami w odniesieniu do alleli G i A wariantu rs7895833; grupy nie różniły się też względem alleli T i C wariantu rs2273773. Przedstawione wyniki wskazują na to, że opisywane polimorfizmy genu SIRT1 mogą być związane z POChP.

Słowa kluczowe: POChP, gen SIRT1. 


\section{Introduction}

Chronic obstructive pulmonary disease (COPD) is an irreversible progressive chronic inflammatory disease that causes shortness of breath in consequence of a decrease in pulmonary functions. Chronic obstructive pulmonary disease is the fourth most frequent cause of death in the world and it is still a serious global public health concern. While the COPD prevalence is about $10 \%$ in Turkey, its prevalence in the EU countries is 3.1\%. The prevalence in the developing countries is higher than in the developed countries because of bad living conditions and excessive smoking. In the end, chronic airflow obstruction and other physiological abnormalities incident to COPD occur. The pulmonary inflammatory pathogenesis is multifactorial. Chronic obstructive pulmonary disease progresses slowly. Long-term exposure to the affecting factors causes this disease and therefore this illness is observed in elderly patients. The A1-antitrypsin (a1-AT) gene, some oxidants, chemical compounds, cigarette smoke, toxic gases, free radicals and environmental factors play a role in COPD development. Cigarette smoking is the most important among these risk factors for COPD. However, we have too little up-to-date information about the relation between COPD and genetics [1-5].

Sirtuin 1 (SIRT1) is a protein/histone deacetylase dependent NAD. It plays a crucial role in various human diseases such as cardiovascular diseases, cancer, inflammation, aging, neurodegenerative disease, obesity and type 2 diabetes. Seven isoforms of the SIRT1 gene (SIRT1SIRT7) have been determined in mammals. Expression of the SIRT1 gene is regulated by transcription factors such as CREB, FOXO3, HIC1, NF-KB, p53, PARP-2 and PPAR. SIRT1 deacetylates $\mathrm{FOXO3}$, which has a regulatory role in the pulmonary inflammatory response. The SIRT1 gene, which has a role in the nucleus and cytoplasm, encodes deacetylase enzyme, and this enzyme is important for energy metabolism, fatty tissue and bone tissue of mammals [6, 7]. Some recent research shows that SIRT1 transcription affects gluconeogenesis, insulin secretion, cellular life, prevention of gene damage, response to DNA damage, stress management, aging and metabolism $[7,8]$.

The aim of this study is to analyze the relation between rs7895833, rs7069102 and rs2273773, mononucleotide polymorphisms of the SIRT1 gene, between 100 COPD patients and a control group consisting of 100 healthy persons, by using various laboratory data and polymerase chain reaction (PCR) with the confronting 2-pair primers (CTPP) assay method.

\section{Material and methods \\ Participants}

The protocol was approved by the regional ethical committee and made according to the principles of the Helsinki Declaration. One hundred COPD patients, who were diagnosed through GOLD guideline standards, were analyzed. The onset of illness, the character, place, ache time and history of illness, the accompanying symptoms and the medication reports were examined in the analysis. One hundred COPD patients from the archive records of the Chest Diseases Department of Muğla Sitki Kocman University Medical Faculty, who did not have any other chronic disease, were included in the study. A control group was formed from 100 healthy individuals living in the same geographical region.

\section{Genotyping}

After receiving written informed consent, 20 cc of blood was taken from both groups. Peripheral blood leucocytes were separated by using the DNA Isolation Kit (Thermo K0772) according to the instructions of Genomic DNA producer and it was kept at $-20^{\circ} \mathrm{C}$. SIRT1 genotypes were determined using PCR and CTPP methods [9] (Table I). Genotyping was implemented for the rs7895833 polymorphism of the SIRT1 gene: 320, 241 bp for AA genotype; 320, 241, 136 bp for AG genotype; and 320, 136 bp for GG genotype. For the rs7069102 polymorphism of the SIRT1 gene, genotyping was performed as follows: 391, 277 bp for CC genotype; 391, 277, 167 bp for CG genotype; and 391, 167 bp for GG genotype. Also, for the rs2273773 polymorphism of the SIRT1 gene, genotyping was performed as follows: 314, 228 bp for CC genotype; 314, 228, 135 bp for CT genotype; and 314, 135 bp for TT genotype (Figs. 1A-C).

\section{Statistical analysis}

The program Statistical Package for the Social Sciences (SPSS) 21 was used in the analysis of the data. For the analysis of the conformity of quantitative data to the normal distribution, the Shapiro-Wilk test was used. In the comparison of 2 independent groups, the independentsamples $t$-test was used. In the comparison of categorical data, Pearson's $\chi^{2}$ (exact) test was used. The quantitative values are shown in the tables as mean \pm SD. (standard deviation) values. The categorical values are shown as $n$ (number) and percentage (\%). The data were analyzed at the $95 \%$ confidence level, and the $p$ value was accepted as significant if less than 0.05 .

\section{Analysis results}

All patients were taken from Muğla Sitki Kocman University Medical Faculty, Department of Chest, Turkey. Among 100 patients with COPD, 60 were men and 40 were women. The average age was 65.92. In the control group 55 were men and 45 were women; the average age was 49.54 While there was no significant difference between groups with regards to gender, a significant difference was found with regard to age. As the study carried out was a genotype study, the significant difference in age was not considered remarkable. The age and gender distribution of the persons included in the study and their $p$ values are given in Table II. The SIRT1 gene genotypes and allele distributions of the patients with COPD and the control group in the Muğla region are presented in Tables III and IV. The distribution of 
Tab. I. Primers and annealing temperature used for rs7895833, rs7069102, and rs2273773 polymorphisms of SIRT1 gene

\begin{tabular}{|c|c|c|c|c|}
\hline Gene & Polymorphism & $\begin{array}{l}\text { Primers sequence } \\
\qquad 5^{\prime}-3^{\prime}\end{array}$ & $\begin{array}{c}\text { Ann. temp. } \\
\left({ }^{\circ} \mathrm{C}\right)\end{array}$ & Fragment size (bp) \\
\hline \multirow[t]{12}{*}{ SIRT1 } & rs7895833 & CCCAGGGTTCAACAAATCTATGTTG & 64 & \\
\hline & & GGTGGTAAAAGGCCTACAGGAAA & & AA; 320, 241 bp \\
\hline & & GCTTCCTAATCTCCATTACGTTGAC & & AG; 320, 241,136 bp \\
\hline & & CCTCCCAGTCAACGACTTTATC & & GG; 320, 136 bp \\
\hline & rs7069102 & GTAGCAGGAACTACAGGCCTG & 64 & \\
\hline & & GAGAAGAAAGAAAGGCATAATCTCTGC & & CC; 391, 277 bp \\
\hline & & СTATCTGCAGAAATAATGGCTTTTCTC & & CG; 391, 277, 167 bp \\
\hline & & GATCGAGACCATCCTGGCTAAG & & GG;391, 167 bp \\
\hline & rs2273773 & GTGTGTCGCATCCATCTAGATAC & 63 & \\
\hline & & СTCTCTGTCACAAATTCATAGCCT & & CC; 314, 228 bp \\
\hline & & GTAGTTTTCCTTCCTTATCTGACAG & & CT; 314, 228, 135 bp \\
\hline & & CTGAAGTTTACTAACCATGACACTG & & TT; 314, 135 bp \\
\hline
\end{tabular}

A

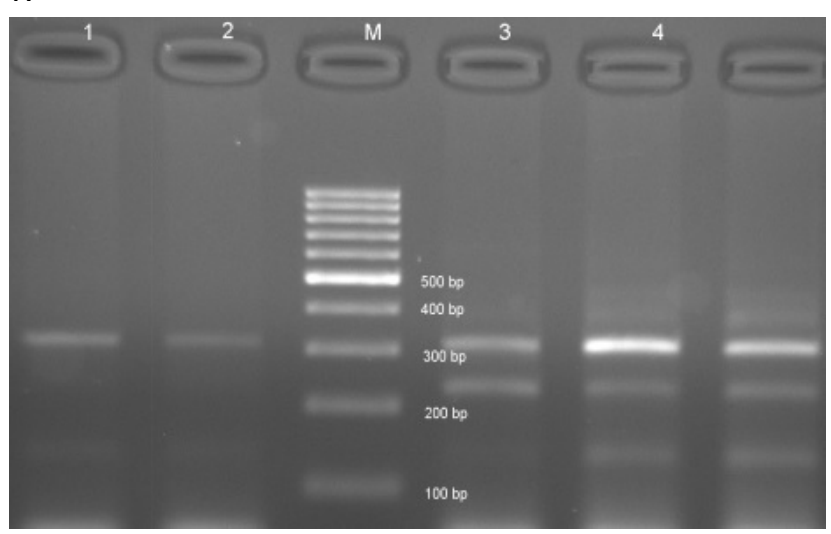

C

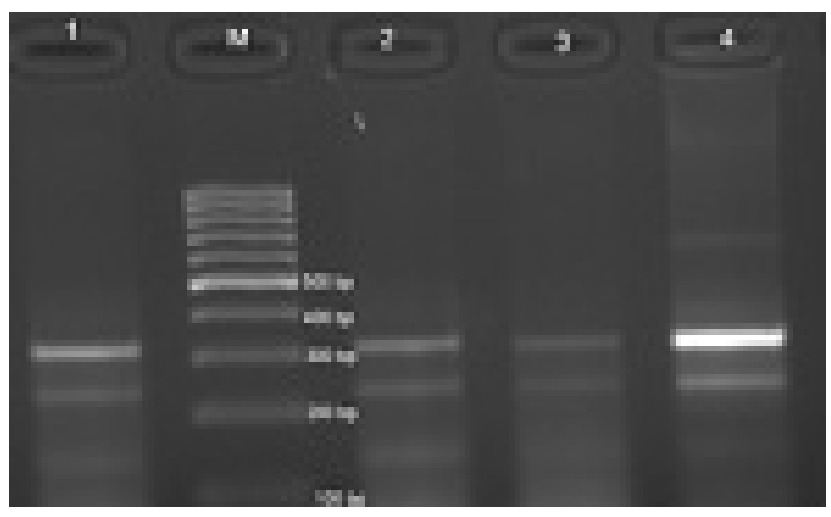

Tab. II. Demographic characteristics of patients and controls

\begin{tabular}{lccc} 
Factors & $\begin{array}{c}\text { COPD } \\
(n=100)\end{array}$ & $\begin{array}{c}\text { Control } \\
(n=100)\end{array}$ & $p$ value \\
Age (mean \pm SD $)$ & $65.92 \pm 8.76$ & $49.54 \pm 10.80$ & $<0.001$ \\
\hline Sex (male/female) & $60 / 40$ & $55 / 45$ & 0.567 \\
\hline
\end{tabular}

Independent $t$ test - Pearson $\chi^{2}$ (exact), SD - standard deviation
B

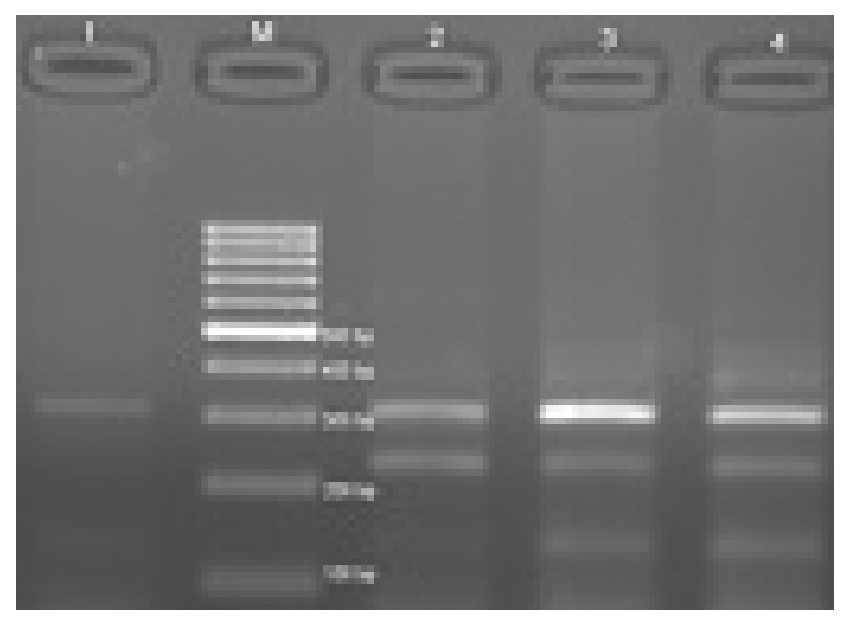

Fig. 1. A) Genotyping analysis of SIRT1 gene rs7895833 polymorphism; 1 and 2 numbers of subjects have GG genotype, 3 number of subject has AA genotype, 4 number of subject has AA genotypes. B) Genotyping analysis of SIRT1 gene rs7069102 polymorphism; 1 - number of subject has GG genotypes, 2 - number of subject has CC genotypes, 3 and 4 - numbers of subjects have CG genotype. C) Genotyping analysis of SIRT1 gene rs2273773 polymorphism; 1 and 2 - numbers of subjects have CT genotypes, 3 and $4-$ numbers of subjects have CC genotype

the SIRT1 gene for the persons in the COPD and control groups was in Hardy-Weinberg equilibrium.

While GG, AG and AA genotype frequencies of rs7895833 were $20 \%, 60 \%$ and $17 \%$ respectively for the group with COPD, these were $36 \%, 47 \%$ and $17 \%$ for the control group $(p=0.033)$. While the frequencies of $\mathrm{G}$ and $\mathrm{A}$ alleles of the group with COPD were $51.5 \%$ and $48.5 \%$, these were $59.5 \%$ 
Tab. III. Distribution of genotypes of patients and controls

\begin{tabular}{|c|c|c|c|c|c|}
\hline Gene name & SNP & Genotypes & Control, $n(\%)$ & COPD, $n(\%)$ & $p$ value \\
\hline \multirow[t]{9}{*}{ SIRT1 } & \multirow[t]{3}{*}{ rs7895833 } & GG & $36(36 \%)$ & $20(20 \%)$ & \multirow[t]{3}{*}{0.033} \\
\hline & & AG & 47 (47\%) & $63(63 \%)$ & \\
\hline & & AA & 17 (17\%) & 17 (17\%) & \\
\hline & \multirow[t]{3}{*}{ rs7069102 } & CC & $43(43 \%)$ & $41(41 \%)$ & \multirow[t]{3}{*}{0.981} \\
\hline & & CG & $41(41 \%)$ & $43(43 \%)$ & \\
\hline & & GG & $16(16 \%)$ & $16(165)$ & \\
\hline & \multirow[t]{3}{*}{ rs2273773 } & TT & $33(33 \%)$ & $25(25 \%)$ & \multirow[t]{3}{*}{0.01} \\
\hline & & TC & $50(50 \%)$ & 39 (39\%) & \\
\hline & & CC & 17 (17\%) & 36 (36\%) & \\
\hline
\end{tabular}

*Pearson $\chi^{2}$ (exact)

Tab. IV. Allele frequencies for COPD patients and control subjects

\begin{tabular}{lcccc} 
SNP & Allele & Control, $n(\%)$ & Patient, $n(\%)$ & $p$ value \\
rs7895833 & G & $119(59.5 \%)$ & $103(51.5 \%)$ & 0.131 \\
\cline { 2 - 4 } & A & $81(40.5 \%)$ & $97(48.5 \%)$ & 0.918 \\
\cline { 2 - 4 } rs7069102 & C & $127(63.5 \%)$ & $125(62.5 \%)$ & $75(37.5 \%)$ \\
\hline rs2273773 & G & $73(36.5 \%)$ & $89(44.5 \%)$ & 0.009 \\
\hline & T & $116(58 \%)$ & $111(55.5 \%)$ & \\
\hline
\end{tabular}

* Pearson $\chi^{2}$ (exact)

and $40.5 \%$ for the control group ( $p=0.131$ ). While CC, CG and GG genotype frequencies of rs 7069102 were $41 \%, 43 \%$ and $16 \%$ respectively for the group with COPD, these were $43 \%, 41 \%$ and $16 \%$ for the control group ( $p=0.981)$. While the frequencies of $\mathrm{C}$ and $\mathrm{G}$ alleles of the group with COPD were $62.5 \%$ and $37.5 \%$, these were $63.5 \%$ and $36.5 \%$ for the control group ( $p=0.918$ ). While TT, TC and CC genotype frequencies of rs 2273773 were $25 \%, 39 \%$ and $36 \%$ respectively for the group with COPD, these were 33\%, 50\% and 17\% for the control group $(p=0.981)$. While the frequencies of T and $C$ alleles of the group with COPD were $44.5 \%$ and $55.5 \%$, these were $58 \%$ and $42 \%$ for the control group ( $p=0.009)$ (Tables III and IV).

A significant difference was found between $G G, A G$ and AA genotypes of rs7895833. Especially the AG genotype was found in the group with COPD with a significant difference. While there was no change in the percentages of AA genotype in the same group, the analysis showed that the percentages were significantly lower in the GG genotype. A significant difference was found between TT, TC and CC genotypes of rs2273773. As the TC genotype's rate of incidence was decreasing, it was determined that the rate of incidence for the $C C$ gene increased more than twice. A significant difference was not found in both groups for CC, CG and GG genotypes of rs7069102. It shows that these polymorphisms of the SIRT1 gene could be associated with the COPD tendency of the population from Muğla.

There was a significant difference between the two groups with regards to $C$ and $G$ alleles of rs7069102. While the percentage of the T allele, which was dominant in the control group, was decreasing in the group with COPD, the $C$ allele, which was seen less often in the control group, was determined as more dominant in the group with COPD. While no difference was found in both groups with regards to $G$ and $A$ alleles of rs7895833, a high rate of $\mathrm{G}$ allele was determined in both groups. A difference was not found in both groups with regards to $T$ and $C$ alleles of rs2273773. A dominant rate of $C$ allele was also found in this group.

\section{Discussion}

Chronic obstructive pulmonary disease is one of the important public health concerns. The COPD pathophysiology is associated with an inflammatory cell profile that contains macrophages, neutrophils and $\mathrm{T}$ lymphocytes. The early diagnosis of COPD is important, because it is a remediable illness with early diagnosis. Oxidative stress, proteinases, proinflammatory mediators, cytokines and chronic irritants play an important role in chronic inflammation development for COPD [1-3]. Oxidative stress increases transcription factors. The SIRT1 gene plays an important role in the 
formation of NF-kB dependent proinflammatory cytokines. However, this role of SIRT1 is not known for COPD.

The SIRT1 gene is located on the 10q21.3 chromosome [6]. It encodes the enzyme group that has tasks such as gene transcription, DNA replication and DNA repair. The relation between SIRT1 polymorphisms and some diseases such as cardiovascular diseases, obesity and type 2 diabetes has been researched. A single gene polymorphism has been found in the SIRT1 gene for these illnesses and reported [8-11]. Botden et al. reported that there was an interaction between type 2 diabetes, which is seen in adults, and rs7895833 [12]. With the studies carried out, it was documented that the SIRT1 gene was involved in COPD pathogenesis [7, 8]. In the study performed by Yao et al., they determined that there was a decrease in SIRT1 levels in the lungs of patients with COPD [13]. Additionally, Rajendrasozhan et al. reported that nuclear SIRT1 protein was at low levels in lung epithelial cells of patients with COPD [14]. These results show that SIRT1 protein is a safeguard against inflammation.

In company with these studies, we planned to investigate the changes in genotype and alleles of the SIRT1 gene in patients with COPD. In our study, we analyzed rs7895833, rs7069102 and rs2273773 polymorphisms in the SIRT1 gene. As far as we know, this is the first study where SIRT1 gene polymorphism has been investigated in patients with COPD.

In our study, a significant difference was found between GG, AG and AA genotypes of rs7895833 and particularly the AG genotype was significantly more frequent in the group with COPD. Moreover, a significant difference was also found between TT, TC and CC genotypes of rs2273773. As the incidence rate of TC genotype decreases, it has been determined that the incidence rate had increased more than twice in CC gene. It shows that these polymorphisms of the SIRT1 gene could be associated with the COPD tendency of the population from Muğla.

There was a significant difference between the two groups with regards to $C$ and $G$ alleles of rs7069102. As the $T$ allele, which is dominant in the control group, was decreasing in the group with COPD, the $C$ allele, which is seen less frequently in the control group, was determined as more dominant in the group with COPD.

These studies, performed at low cost through easily accessible equipment, support the usability of these genotypes and alleles for a more precise and objective diagnosis of COPD.

At the end of this study, we found an association between rs7895833 and rs2273773 polymorphisms of the SIRT1 gene and COPD illness. No association between the SIRT1 gene and COPD could be shown in any previous study. In more prospective studies, the SIRT1 gene expression and mutations should be analyzed with a bigger COPD patient group. Moreover, additional studies are needed to clarify the SIRT1 gene's role in the pathogenesis of COPD.

\section{Conclusions}

The study showed that rs7895833 and its polymorphisms in the SIRT1 gene and T and C alleles of the rs2273773 polymorphism could be important for the diagnosis of COPD in Muğla province and the surrounding region.

\section{Acknowledgements}

We are grateful to Muğla Sitki Kocman University hospital. We are also grateful to Muğla Sitki Kocman University School of Medicine.

\section{Disclosure}

The authors report no conflict of interest.

\section{References}

1. Baris SA, Yildiz F, Basyigit I, Boyaci H, Ilgazli A. Prevalence of smoking and chronic obstructive pulmonary disease amongst teachers working in Kocaeli, Turkey. Multidiscip Respir Med 2011; 6: 92-96.

2. Tertemiz KC, Komus N, Ellidokuz H, Sevinc C, Cimrin AH. Mortality and factors affecting mortality in chronic obstructive pulmonary disease. Tuberk Toraks 2012; 60: 114-122.

3. Wu X, Yuan B, Lopez E, Bai C, Wang X. Gene polymorphisms and chronic obstructive pulmonary disease. J Cell Mol Med 2014; 18: 15-26.

4. Knobloch J, Wahl C, Feldmann M, Jungck D, Strauch J, Stoelben E, Koch A. Resveratrol attenuates the release of inflammatory cytokines from human bronchial smooth muscle cells exposed to lipoteichoic acid in chronic obstructive pulmonary disease. Basic Clin Pharmacol Toxicol 2014; 114: 202209.

5. Yang SR, Chida AS, Bauter MR, Shafiq N, Seweryniak K, Maggirwar SB, Kilty I, Rahman I. Cigarette smoke induces proinflammatory cytokine release by activation of NF-kappaB and posttranslational modifications of histone deacetylase in macrophages. Am J Physiol Lung Cell Mol Physiol 2006; 291 : L46-57.

6. Zarrabeitia MT. Association study of sirtuin 1 polymorphisms with bone mineral density and body mass index. Arch Med Res 2012; 43: 363-368.

7. Rahman I, Kinnula VL, Gorbunova V, Yao H. SIRT1 as a therapeutic target in inflammaging of the pulmonary disease. Prev Med 2012; 54 Suppl: S20-28.

8. Chung S, Yao H, Caito S, Hwang JW, Arunachalam G, Rahman I. Regulation of SIRT1 in cellular functions: role of polyphenols. Arch Biochem Biophys 2010; 501: 79-90.

9. Shimoyama Y, Suzuki K, Hamajima N, Niwa T. Sirtuin 1 gene polymorphisms are associated with body fat and blood pressure in Japanese. Transl Res 2011; 157: 339-347.

10. Cui Y, Wang H, Chen H, Pang S, Wang L, Liu D, Yan B. Genetic analysis of the SIRT1 gene promoter in myocardial infarction. Biochem Biophys Res Commun 2012; 426: 232-236.

11. Peeters AV, Beckers S, Verrijken A, Mertens I, Roevens P, Peeters PJ, Van Hul W, Van Gaal LF. Association of SIRT1 gene variation with visceral obesity. Hum Genet 2008; 124: 431-436.

12. Botden IP, Zillikens MC, de Rooij SR, Langendonk JG, Danser AH, Sijbrands EJ, Roseboom TJ. Variants in the SIRT1 gene may affect diabetes risk in interaction with prenatal exposure to famine. Diabetes Care 2012; 35: 424-426.

13. Yao H, Chung S, Hwang JW, Rajendrasozhan S, Sundar IK, Dean DA, McBurney MW, Guarente L, Gu W, Rönty M, Kinnula VL, Rahman I. SIRT1 protects against emphysema via FOXO3-mediated reduction of premature senescence in mice. J Clin Invest 2012; 122: 2032-2045.

14. Rajendrasozhan S, Yang SR, Kinnula VL, Rahman I. SIRT1, an antiinflammatory and antiaging protein, is decreased in lungs of patients with chronic obstructive pulmonary disease. Am J Respir Crit Care Med 2008; 177: 861-870. 